\title{
Predicting financial stability of select BSE companies revisiting Altman $Z$ score
}

\author{
Vineet Chouhan ${ }^{1, a}$, Bibhas Chandraa ${ }^{2, b}$, Shubham Goswami ${ }^{1, c}$ \\ 1School of Management, Sir Padampat Singhania University, Bhatewar, Udaipur, Rajasthan, India \\ a,c Mobile: +91-9772778431, +91-9461347456 \\ ${ }^{2}$ Management Department, Indian School of Mines, Dhanbad, Jharkhand, India \\ a,b,cE-mail address: vineet.chouhan@spsu.ac.in , chandra_bibhas@yahoo.co.in , \\ shubham.goswami@spsu.ac.in
}

\begin{abstract}
In the era of globalization, prediction of financial distress is of interest not only to managers but also to external stakeholders of a company. The stakeholders are continuously seeking the optimal solution for performance forecasting, as a way to rationalize the decision-making process. The recent past shows that financial stability of companies is at the stake. Stockholders, Managers, Creditor and employees of the business are always concerned about financial stability of the companies. The most frequently tool for financial analysis is financial ratios. However, financial ratios are no-longer proved appropriate for 'Stockholders' equity position and creditors' claims. Stakeholder's have concerns about the consequences of financial distress for companies, and controls of capital adequacy through the regulatory capital requirement (Mingo, 2000). This shared interest creates persistent investigations and continuing attempts to answer an incessant question that how financial distress can be predicted, or what reveals the credit risk of firms. For this purpose most commonly used tool is Altman Z score, but due to nature of the explanatory variables, financial distress prediction research has not reached an unequivocal conclusion. The primary goal of this paper is to analyze and reexamine the Altman $Z$ score. In order to facilitate the current research, various ratios were taken from Altman's Z score. To fulfill our objective $Z$ score ratios were used to divide sample firms into healthy and unstable among BSE-30 companies. First the $\mathrm{Z}$ score is calculated for 10 companies selected for this purpose for a period of 5 years each. And then it is divided as per $\mathrm{z}$ scores, later the significant in the changes in the ratio is calculated with the help of One sample Komogrov-Smirnow test, which resulted that the change in the $\mathrm{z}$ scores is not significant in case of all the companies.
\end{abstract}

Keywords: companies; Komogrov-Smirnow; Stockholders; Managers; Creditor; employees of the business

\section{INTRODUCTION}

Ratio analysis is used in various part of the world for measuring financial accuracy and creditworthiness of the firms, but, Academician seems to be moving toward the elimination of ratio analysis as an analytical technique in assessing the performance of the business enterprise. Theorists downgrade arbitrary rules of thumb, such as company ratio comparisons, widely used by practitioners. Since attacks on the relevance of ratio analysis emanate from many esteemed 
members of the scholarly world, which mean that ratio analysis is limited implications and it has the significance of such an approach been unattractively garbed. We have to bridge the gap, between traditional ratio "analysis" and the more rigorous statistical techniques.

The detection of company operating and financial difficulties is a subject which has been particularly susceptible to financial ratio analysis (Chouhan et. al, 2010, 2011 ${ }^{\mathrm{a}, \mathrm{b}}$ ). Prior to the development of quantitative measures of company performance, agencies were established to supply a qualitative type of information assessing the creditworthiness of particular merchants. Formal aggregate studies concerned with portents of business failure were evident in the 1930 's.

Altman (1968) was the first researcher to apply the Multiple Discriminant Analysis (MDA) approach to the financial distress prediction domain. He developed a Z-score bankruptcy prediction model and determined a cut point of Z-score (2.675) to classify healthy and distressed firms. The results showed that the Z-score model had sound prediction performance one year and two years before financial distress, but did not indicate good prediction utility three to five years before financial distress. A number of authors followed atman's work, and applied the Z-score model into different markets, different time periods and different industries, such as, Taffler (1982, 1984), Pantalone and Platt (1987), Betts and Belhoul (1987) and Piesse and Wood (1992).

\section{1. Multiple Discriminant Analysis}

MDA assumes that the covariance matrices of two populations are identical and both populations need to be described by multivariate normal distribution. Clearly, these assumptions do not always reflect the real world. Deakin (1976) argued that even if after performing the normality transforming process, financial ratio data do not follow normal distribution. Moreover, Hamer (1983) evaluated the sensitivity of financial distress prediction models in terms of four different variable sets from previous research (Altman, 1968; Deakin, 1972; Blum, 1974; Ohlson, 1980) and she pointed out that the covariance matrices in each variable set were statistically different. Beaver (1967) was the first to identify the characteristics of failing firms in comparison to a matched paired sample of healthy firms. Using univariate discrimination test and found that financial ratios are proved to be useful predictors and found that certain financial ratios can be very useful predictors of failure even five years before it happens.

This study can be thought of as the pioneering work which initiated a series of other works in the same area. Following this first study two major statistical techniques, Multiple Discriminant Analysis (MDA) and Regression Analysis (RA), were applied by many authors to predict imminent bankruptcies. E. Altman $(1968,1978)$ was the first to apply the MDA method to the failure prediction problem and his model (known as Z Score analysis) was $90 \%$ accurate in classifying firms correctly one year prior to failure. In other methods, Regression Analysis was applied by Edmister (1971) who obtained high classification results. However, one major shortcoming was the fact that he did not use the variables in their raw form but, instead, he transformed each. MDA was also applied by Deakin (1972) who found that his models were at least $95 \%$ accurate for the first three years prior to bankruptcy.

The two techniques (MDA and RA) were compared in a study by Collins (1980) who concluded that both methods provided good predictive results. In Japan a number of studies (for example, Nikkei-Business, Takahashi and Ko) obtained high classification performances (85\% or above). Von Stein (1981) in Germany, Weibel (1973) in Switzerland, Taffler et al and Tissaw (1977) and Marais (1979) in England, Bilderbeek (1977) in Netherlands and Altman and Lavallee (1981) in Canada used MDA. In all of these studies the estimated models had 
high success rates ranging from $70 \%$ to $90 \%$. Similar studies by Altman (1973) in France and Castagna and Matolscy (1981) in Australia obtained average results.

Generalized linear models or multiple logistic regression models are also popular. Ohlsons O-Score (Ohlson, 1980) is based on generalized linear models with the logit link function, also referred to as logit analysis. Neural network models are powerful and popular alternatives, with the ability to incorporate a very large number of features in an adaptive nonlinear model, Wilson and Sharda (1994). In India prediction models have been developed by Gupta (1979), Kaveri (1980), Srivastava (1981), and Yadav (1986). Gupta (1979) has made an attempt to examine a variety of ratios and determined the best set of ratios. Yadav (1986) developed discriminant model by using financial ratios which covers the financial characteristics of the firm. Rekha Pai et al (2006) has made a comparison of PCA-MDA model and Neural networks techniques to predict industrial sickness and has proved that the traditional statistical model seem to perform as a better predictive technique than the soft computing model. Regardless of the advantages or the disadvantages of the predictive model, the very idea of developing such models to predict financial distress and failure itself is welcome allover, for a model could help to detect the likelihood of forthcoming sickness and thus facilitate to prevent its onslaught in an early stage. The bankruptcy models can be used as early warning signals, such that, corrective action may be undertaken immediately by the management.

The paper begins with a literature review on the credit risk measure, followed by discussion on the option-based credit risk measure. The paper also describes the data collected, the variables analyzed and the statistical methods adopted in the paper. We conclude, after statistical results for the Altman's Z-score and the comparison with the option-based measure are discussed.

\subsection{Objectives}

The main objectives of the current study are enlisted as below:

1. To calculate the prominent ratios of select BSE-30 companies included in Altman Z score.

2. To identify the change in time series data correspond to Altman Z score for each select BSE-30 companies.

\section{REVIEW OF LITERATURE}

The first multivariate study was published by Altman (1968). He has used multivariate discriminant analysis to develop a five-factor model to predict bankruptcy of manufacturing firms. The "Z-score", as it was called, predicted bankruptcy if the firm's score fell within a certain range.

Initiated by Beaver (1966), Altman (1968), and Ohlson (1980), academic studies to measure financial vulnerability continued for three decades. Beaver found that the cash flow to debt ratio was the best single ratio predictor of distress in his univariate discriminant analysis. Altman's Z-Score model used multivariate discriminant analysis to select the five most significant variables for measuring the financial distress of firms. Ohlson's O-Score model used a logit analysis to generate a one-year prediction model, and his academic descendants frequently referred to his discrete variables as a proxy for the probability of financial distress.

Altman (1968) collected data from 33 failed firms and 33 matching firms, during the period 1946-1965, to find discriminating variables for bankruptcy prediction. In his seminal 
paper, Altman evaluated 22 potentially significant variables of the 66 firms by using multiple discriminant analysis to build the discriminant function with five variables. The discriminant function is as follows:

$$
Z=1.2 X_{1}+1.4 X_{2}+3.3 X_{3}+0.6 X_{4}+0.999 X_{5}
$$

where:

$$
\begin{aligned}
& X_{1} \equiv \text { Working Capital/Total Assets } \\
& X_{2} \equiv \text { Retained Earnings/Total Assets } \\
& X_{3} \equiv \text { EBIT/Total Assets } \\
& X_{4} \equiv \text { Market Value of Equity/Book Value of Total Debt, and } \\
& X_{5} \equiv \text { Sales/Total assets }
\end{aligned}
$$

\section{X1-Working Capital/Total Assets}

The Working capital/Total assets ratio, frequently found in studies of corporate problems, is a measure of the net liquid assets of the firm relative to the total capitalization. Working capital is defined as the difference between current assets and current liabilities. Liquidity and size characteristics are explicitly considered. Ordinarily, a firm experiencing consistent operating losses will have shrinking current assets in relation to total assets. Of the three liquidity ratios evaluated, this one proved to be the most valuable. 22 Inclusion of this variable is consistent with the Merwin study which rated the net working capital to total asset ratio as the best indicator of ultimate discontinuance.

\section{X2-Retained Earnings/Total Assets}

This measure of cumulative profitability over time was cited earlier as one of the "new" ratios. The age of a firm is implicitly considered in this ratio. For example, a relatively young firm will probably show a low RE/TA ratio because it has not had time to build up its cumulative profits. Therefore, it may be argued that the young firm is somewhat discriminated against in this analysis, and its chance of being classified as bankrupt is relatively higher than another, older firm. But, this is precisely the situation in the real world. The incidence of failure is much higher in a firm's earlier.

\section{X3-Earnings before Interest and Taxes/Total Assets}

This ratio is calculated by dividing the total assets of a firm into its earnings before interest and tax reductions. In essence, it is a measure of the true productivity of the firm's assets, abstracting from any tax or leverage factors. Since a firm's ultimate existence is based on the earning power of its assets, this ratio appears to be particularly appropriate for studies dealing with corporate failure. Furthermore, insolvency in a bankruptcy sense occurs when the total liabilities exceed a fair valuation of the firm's assets with value determined by the earning power of the assets.

\section{X4-Market Value of Equity/Book Value of Total Debt}

Equity is measured by the combined market value of all shares of stock, preferred and common, while debt includes both current and long-term. The measure shows how much the firm's assets can decline in value (measured by market value of equity plus debt) before the 
liabilities exceed the assets and the firm becomes insolvent. This ratio adds a market value dimension which other failure studies did not consider. It also appears to be a more effective predictor of bankruptcy than a similar, more commonly used ratio: Net worth/Total debt (book values).

\section{X5-Sales/Total Assets}

The capital-turnover ratio is a standard financial ratio illustrating the sales generating ability of the firm's assets. It is one measure of management's capability in dealing with competitive conditions. This final ratio is quite important because, as indicated below, it is the least significant ratio on an individual basis. In fact, based on the statistical significance measure, it would not have appeared at all. However, because of its unique relationship to other variables in the model, the Sales/Total assets ratio ranks second in its contribution to the overall discriminating ability of the model.

The Z-Score, which as aforementioned is a survival indicator, classifies companies based on their solvency. The higher the value is, the lower the risk of bankruptcy. A low or negative Z-Score indicates high likelihood of bankruptcy. Altman set critical values between companies based on the survivability indicator which is given in table-1 as under:

Table 1. Critical values of Altman's Model.

\begin{tabular}{|c|c|c|}
\hline Score & Zone & Result \\
\hline $\mathrm{Z}<1.81$ & Distress & likely to be bankrupt \\
\hline $1.81<\mathrm{Z}<2.99$ & Gray Zone & Stable \\
\hline $\mathrm{Z}>2.99$ & Safe Zone & Safe \\
\hline
\end{tabular}

Altman finds that the prediction accuracy of the model tapers off for longer prediction horizons such as four- and five-year horizons. Accuracy tapers from $95 \%$ for 1 -year and $72 \%$ for 2-year prediction horizon, to $48 \%$ for 3-year, $29 \%$ for 4 -year and $36 \%$ for 5-year horizon. Literature on bankruptcy had identified many ratios that were important in predicting bankruptcy. The Contributors to informational inputs used in models predicting bankruptcy is shown in Table 2.

Many Study found better performance of Altman z-model for manufacturing companies (Grice and Ingram: 2001; Christopoulos et al. 2007). Over the past decade, the Z-score models were used as a proxy for bankruptcy risks in such areas as strategic planning (Calandro, 2007), investment decisions (Sudarsanam and Lai, 2001; Lawson, 2008), asset pricing (Griffin and Lemmon, 2002; Ferguson and Shockley, 2003), capital structure (Allayannis et al., 2003; Molina, 2005), credit risk pricing (Kao, 2000; Jayadev, 2006), distressed securities (Altman, 2002: ch. 22; Marchesini et al., 2004) and going-concern research (Citron and Taffler, 2004; Taffler et al., 2004). 
Table 2. Reviews of literature.

\begin{tabular}{|c|c|c|c|}
\hline Author & Sample/ Country & $\begin{array}{c}\text { Efficiency \& type of } \\
\text { ratio }\end{array}$ & Result \\
\hline $\begin{array}{l}\text { Lifschutz } \\
\text { and Jacobi } \\
\quad(2010)\end{array}$ & $\begin{array}{c}\text { Publicly traded } \\
\text { companies in Israel } \\
\text { between } 2000 \text { and } \\
2007\end{array}$ & $\begin{array}{l}95 \% \text { accuracy rate one } \\
\text { year prior to bankruptcy } \\
\text { and with an } 85 \% \\
\text { accuracy rate } \\
\text { two years prior to } \\
\text { bankruptcy }\end{array}$ & $\begin{array}{l}\text { It predicts that higher index } \\
\text { predicts a high likelihood of } \\
\text { survival, } \\
\text { while a lower index predicts } \\
\text { low likelihood of survival }\end{array}$ \\
\hline $\begin{array}{l}\text { Alkhatib } \\
(2011)\end{array}$ & $\begin{array}{c}\text { Jordanian companies } \\
\text { during the five years } \\
\text { preceding the } \\
\text { bankruptcy }\end{array}$ & $\begin{array}{l}\text { Bankruptcy incident } \\
\text { high rates of } 75 \% \text { for the } \\
\text { fifth year, } 94 \% \text { for the } \\
\text { fourth year and } 100 \% \\
\text { for each of the third, the } \\
\text { second and the first. }\end{array}$ & $\begin{array}{l}\text { Main result was percentage } \\
\text { rates and prediction } \\
\text { frequencies for Altman Z- } \\
\text { Score }\end{array}$ \\
\hline $\begin{array}{l}\text { Wang \& } \\
\text { Campbell } \\
(2010)\end{array}$ & $\begin{array}{c}\text { China publicly listed } \\
\text { companies }\end{array}$ & $\begin{array}{l}\text { The accuracy is above } \\
95 \% \text { which confirms } \\
\text { that delisting is a } \\
\text { predictable event. }\end{array}$ & $\begin{array}{l}\text { The models prediction } \\
\text { accuracy rate is in general } \\
\text { depending on the cutoff point } \\
\text { selected models applicable to } \\
\text { China using ex-ante data will } \\
\text { provide meaningful insights. }\end{array}$ \\
\hline $\begin{array}{l}\text { Muller, } \\
\text { Steyn- } \\
\text { Bruwer and } \\
\text { Hamman } \\
(2009)\end{array}$ & $\begin{array}{l}\text { South African } \\
\text { companies listed on } \\
\text { the Johannesburg } \\
\text { Stock Exchange }\end{array}$ & $\begin{array}{l}\text { They found that multiple } \\
\text { discriminant analysis } \\
\text { and recursive } \\
\text { partitioning have the } \\
\text { highest prediction } \\
\text { accuracy for predicting } \\
\text { "failed" companies }\end{array}$ & $\begin{array}{l}\text { Tested the effectiveness of } \\
\text { four different techniques used } \\
\text { to predict financial distress. }\end{array}$ \\
\hline $\begin{array}{l}\text { Yu-Chiang } \\
\text { and Ansell } \\
\text { (2005) }\end{array}$ & $\begin{array}{l}\text { Retail financial } \\
\text { distress anticipatory, } \\
\text { USA, Europe and } \\
\text { Japan, from } 2000 \text { to } \\
2004\end{array}$ & $\begin{array}{c}\text { on five key variables: } \\
\text { Debt Ratio, Total Debt / } \\
\text { (Total Debt + Market } \\
\text { Capitalization), Total } \\
\text { Assets, Operating Cash } \\
\text { Flow and Government } \\
\text { Debt / GDP, Various } \\
\text { Ratio }\end{array}$ & $\begin{array}{l}\text { They used Total Assets as } \\
\text { Scale Measure and results that } \\
\text { results showed that the Z- } \\
\text { score model had sound } \\
\text { prediction performance one } \\
\text { year and two years before } \\
\text { financial distress and Has } \\
\text { constructed a model based } \\
\text { which proved to have sound } \\
\text { classification performance }\end{array}$ \\
\hline $\begin{array}{l}\text { Yair Ingbar } \\
\text { (1994) }\end{array}$ & $\begin{array}{c}\text { Israel's Private } \\
\text { companies data from } \\
\text { the } 1980 \mathrm{~s}\end{array}$ & $\begin{array}{c}93 \% \text { accuracy in } \\
\text { forecasting bankruptcy } \\
\text { one year prior to } \\
\text { collapse and } 73 \% \text { two } \\
\text { years prior to it }\end{array}$ & $\begin{array}{c}\text { Converted the Altman Index } \\
\text { to publicly traded companies } \\
\text { in Israel on Private } \\
\text { companies. }\end{array}$ \\
\hline $\begin{array}{l}\text { Begley et } \\
\text { al. (1996) }\end{array}$ & Data of 1980, US & $\begin{array}{l}\text { Liquidity ratios like } \\
\text { current assets on current } \\
\text { liabilities; current assets }\end{array}$ & $\begin{array}{l}\text { Used the original Altman } \\
\text { Model of 1968, while revising } \\
\text { the coefficients The study } \\
\text { showed that revising the }\end{array}$ \\
\hline
\end{tabular}




\begin{tabular}{|c|c|c|c|}
\hline & & $\begin{array}{l}\text { less inventory on current } \\
\text { liabilities; current assets } \\
\text { less inventory on total } \\
\text { assets; funds from } \\
\text { operations } \\
\text { on total liabilities }\end{array}$ & $\begin{array}{l}\text { coefficients negatively } \\
\text { impacted on the forecasting } \\
\text { ability compared to the } \\
\text { original model. }\end{array}$ \\
\hline $\begin{array}{l}\text { Aziz and } \\
\text { Dar (2006) }\end{array}$ & $\begin{array}{l}\text { reviewed } 89 \text { studies } \\
\text { on prediction of } \\
\text { bankruptcy between } \\
1968-2003\end{array}$ & Various Ratio & $\begin{array}{l}\text { They found that the multi- } \\
\text { variable models (Z-Score) and } \\
\text { logit were the most popular in } \\
\text { the } 89 \text { studies. }\end{array}$ \\
\hline $\begin{array}{l}\text { Chung et } \\
\text { al. }(2008)\end{array}$ & $\begin{array}{l}\text { ten failed finance } \\
\text { companies during } \\
\text { 2006-2007 in New } \\
\text { Zealand }\end{array}$ & $\begin{array}{l}\text { insolvency predictive } \\
\text { ability of different } \\
\text { financial ratios }\end{array}$ & $\begin{array}{l}\text { They found that four of the } \\
\text { five Altman (1968) ratios, one } \\
\text { year prior to failure, were } \\
\text { superior to other financial } \\
\text { ratios for predicting corporate } \\
\text { insolvency }\end{array}$ \\
\hline $\begin{array}{l}\text { Ingbar } \\
(1994)\end{array}$ & $\begin{array}{l}40 \text { publicly traded } \\
\text { Israeli companies in } \\
1982-1990 .\end{array}$ & $\begin{array}{l}\text { In terms of the bankrupt } \\
\text { companies, warning } \\
\text { signs could be identified } \\
\text { two and even three years } \\
\text { prior to the onset of the } \\
\text { crisis at the company }\end{array}$ & $\begin{array}{l}\text { indicated that application of } \\
\text { the Altman Model yields good } \\
\text { results both for stable and } \\
\text { bankrupt companies }\end{array}$ \\
\hline $\begin{array}{l}\text { Ben-Horin } \\
\text { (1996) }\end{array}$ & $\begin{array}{c}\text { Adacom company } \\
\text { (which collapsed in } \\
\text { 1994) with data of } \\
\text { 1992-1994 }\end{array}$ & Various Ratio & $\begin{array}{l}\text { Altman Model results } \\
\text { significant results }\end{array}$ \\
\hline $\begin{array}{l}\text { Eden and } \\
\text { Meir } \\
(2007)\end{array}$ & $\begin{array}{l}\text { Shamir Salads } \\
\text { (which collapsed in } \\
\text { 2005) data for } 2003 \\
\text { and } 2004\end{array}$ & Various Ratio & $\begin{array}{c}\text { Prove that the Altman } \\
\text { indicators clearly show that } \\
\text { the companies are in financial } \\
\text { distress. }\end{array}$ \\
\hline $\begin{array}{l}\text { Odipo \& } \\
\text { Itati }(2011)\end{array}$ & $\begin{array}{l}10 \text { failed firms of } \\
\text { Kenyan market }\end{array}$ & $\begin{array}{l}90 \% \text { successful } \\
\text { prediction of the model. }\end{array}$ & $\begin{array}{l}10 \text { non-failed firms analyzed, } \\
9 \text { of them proved that Edward } \\
\text { Altman's financial distress } \\
\text { prediction model was } \\
\text { successful indicating a } 90 \% \\
\text { validity of the model. }\end{array}$ \\
\hline $\begin{array}{l}\text { Gerantonis, } \\
\text { Vergos and } \\
\text { Christopoul } \\
\text { os (2009) }\end{array}$ & $\begin{array}{l}373 \text { companies out } \\
\text { of which } 45 \text { were } \\
\text { bankrupted, listed on } \\
\text { the Athens Stock } \\
\text { exchange, period of } \\
\text { 1999-2006 }\end{array}$ & Various Ratio & $\begin{array}{l}\text { They investigated whether Z- } \\
\text { score models can predict } \\
\text { bankruptcies for a period up } \\
\text { to three years earlier and } \\
\text { show that Altman model } \\
\text { performs well in predicting } \\
\text { failures. }\end{array}$ \\
\hline
\end{tabular}




\begin{tabular}{|c|c|c|c|}
\hline $\begin{array}{l}\text { Vergos and } \\
\text { Christopoul } \\
\text { os et al } \\
(2006)\end{array}$ & $\begin{array}{l}\text { Greek telecom } \\
\text { company failures }\end{array}$ & $\begin{array}{c}\text { predictions and company } \\
\text { announcements may } \\
\text { affect considerably } \\
\text { market prices up to } 18 \\
\text { months before the } \\
\text { announcement of } \\
\text { negative financial results, } \\
\text { they used Various Ratio. }\end{array}$ & $\begin{array}{l}\text { Something that leads to } \\
\text { incorporation of probability of } \\
\text { failure in company prices, and } \\
\text { respective company Altman } \\
\text { z-score that are affected by } \\
\text { market price of shares, well } \\
\text { before the company will } \\
\text { declare bankruptcy. Altman is } \\
\text { useful in predicting. }\end{array}$ \\
\hline $\begin{array}{l}\text { Charitou } \\
\text { and } \\
\text { Trigeogis } \\
(2000)\end{array}$ & $\begin{array}{l}139 \text { firms that filed } \\
\text { bankruptcy between } \\
1983 \text { and } 1994\end{array}$ & $\begin{array}{l}\text { Independently, and } \\
\text { tested some other } \\
\text { accounting variables in } \\
\text { terms of their } \\
\text { discriminating power for } \\
\text { the default probability of } \\
\text { firms of interest. }\end{array}$ & $\begin{array}{c}\text { Significance of each variable } \\
\text { of Altman z-score is } \\
\text { significant. }\end{array}$ \\
\hline $\begin{array}{l}\text { Hillegeist } \\
\text { et al. } \\
(2002)\end{array}$ & $\begin{array}{c}516 \text { bankruptcy } \\
\text { filings between } 1979 \\
\text { and } 1997\end{array}$ & $\begin{array}{l}\text { Adjusted with the firm's } \\
\text { expected return on } \\
\text { assets }\end{array}$ & $\begin{array}{c}\text { Altman's Z-Score by } \\
\text { introducing a unique discrete } \\
\text { hazard methodology and } \\
\text { compared the risk-neutral } \\
\text { default probability. }\end{array}$ \\
\hline Kim (2007) & $\begin{array}{c}\text { They fail to assert } \\
\text { that the option-based } \\
\text { model performs } \\
\text { better than variables } \\
\text { in Altman's Z-score } \\
\text { model }\end{array}$ & $\begin{array}{l}\text { It is losing its prediction } \\
\text { power for long-term } \\
\text { prediction, and its } \\
\text { accuracy is deteriorating } \\
\text { for recent years' data. }\end{array}$ & $\begin{array}{l}\text { Option-based measure } \\
\text { provides significant results as } \\
\text { a 1-year prediction measure } \\
\text { for recent years in individual } \\
\text { industries. }\end{array}$ \\
\hline $\begin{array}{l}\text { Back et al. } \\
\text { (1996) }\end{array}$ & $\begin{array}{l}11 \text { papers to } \\
\text { reexamine } 31 \\
\text { financial ratios }\end{array}$ & $\begin{array}{l}\text { Used three distinctive } \\
\text { statistical techniques } \\
\text { discriminant analysis, } \\
\text { logit regression, and } \\
\text { neural networks. }\end{array}$ & $\begin{array}{l}\text { No consensus has been built } \\
\text { on the best technique and the } \\
\text { most significant explanatory } \\
\text { variables. }\end{array}$ \\
\hline $\begin{array}{l}\text { Altman and } \\
\text { Narayanan } \\
(1971)\end{array}$ & $\begin{array}{l}\text { identify financially } \\
\text { stressed companies }\end{array}$ & Various Ratios & $\begin{array}{l}\text { No statistical method was } \\
\text { consistently dominant }\end{array}$ \\
\hline $\begin{array}{l}\text { Smith and } \\
\text { Winakor } \\
(1935)\end{array}$ & $\begin{array}{l}183 \text { failed firms } \\
\text { from a variety of } \\
\text { industries }\end{array}$ & Various Ratio & $\begin{array}{c}\text { Working Capital to Total } \\
\text { Assets was a far better } \\
\text { predictor of financial } \\
\text { problems }\end{array}$ \\
\hline
\end{tabular}

Smith at al. (1935) concluded that failing firms exhibit significantly different ratio measurements than continuing entities (Merwin, 1942). In addition, another study was concerned with ratios of large asset-size corporations that experienced difficulties in meeting their fixed indebtedness obligation (Hickman 1958). The previous studies involved the analysis of financial ratios in a bankruptcy-prediction context which includes Beaver; 1966, Altman Z score (Altman 1968), Zeta ${ }^{\mathrm{TM}}$ Analysis (Altman et al.,1977), Marc Blum (1974), Merton's (1974), Frederikslust (1978), Ohlson (1980), Taffler, (1983), Back et al, (1995), Back et al, 
(1997); Spanos et al, (1999), Gupta (1979), Kaveri (1980), Srivastava (1981), and Yadav (1986), etc.

Another stream of financial distress literature has been utilizing various statistical methods to predict the bankruptcy of firms. A few significant methods are: multinomial choice models such as logit and/or probit models (Martin, 1977; Santomero and Vinso, 1977; Ohlson, 1980; Zmijewski, 1984), multiple discriminant analysis (Altman, 1968), recursive partitioning (Frydman, Altman and Kao, 2002), neural networks (Altman, Marco and Varetto, 1994), and discrete hazard models (Hillegeist et al., 2002).

\section{1. S\&P BSE SENSEX-The Barometer of Indian Capital Markets}

S\&P BSE SENSEX is treated as The Barometer of Indian Capital Markets compiled in 1986; it is calculated on a "Market Capitalization-Weighted" methodology of 30 component stocks representing large, well-established and financially sound companies across key sectors. The base year of S\&P BSE SENSEX was taken as 1978-79. S\&P BSE SENSEX today is widely reported in both domestic and international markets through print as well as electronic media. It is scientifically designed and is based on globally accepted construction and review methodology. Since September 1, 2003, S\&P BSE SENSEX is being calculated on a free-float market capitalization methodology. The "free-float market capitalization-weighted" methodology is a widely followed index construction methodology on which majority of global equity indices are based; all major index providers like MSCI, FTSE, STOXX, and Dow Jones use the free-float methodology. The growth of the equity market in India has been phenomenal in the present decade. Right from early nineties, the stock market witnessed heightened activity in terms of various bull and bear runs. In the late nineties, the Indian market witnessed a huge frenzy in the 'TMT' sectors. More recently, real estate caught the fancy of the investors. S\&P BSE SENSEX has captured all these happenings in the most judicious manner. One can identify the booms and busts of the Indian equity market through S\&P BSE SENSEX. As the oldest index in the country, it provides the time series data over a fairly long period of time (from 1979 onwards). Small wonder, the S\&P BSE SENSEX has become one of the most prominent brands in the country.

\section{RESEARCH METHODOLOGY AND DATA SOURCE}

\section{1. Sample Selection}

The importance of Indian Equity market can be identified through S\&P BSE SENSEX, as it is the oldest index in the country, it provides the time series data over a fairly long period of time (from 1979 onwards) and became one of the most prominent brands in the country. For the purpose of this research paper 10 companies were selected as a tentative sample on the basis of Convenient Sampling method, which is part of BSE-30 Companies currently operating in India.

\section{2. Data Source}

The data required for the present study are the financial records and financial ratios suggested by Altman for the 10 BSE companies which were collected through the original source i.e., Annual Report from official websites of the companies through internet. The data which included various ratios were calculated through the collected data of annual report and were taken into account for further analysis. 


\section{3. Hypothesis}

Based upon the objectives of the study and supported by extensive literature reviews, the following hypotheses need to be tested:

$\mathbf{H}_{0}$ : The time series data correspond to Altman $\mathrm{Z}$ score for each select BSE-30 companies exhibit a no differences during last 5 years.

$\mathbf{H}_{1}$ : The time series data correspond to Altman Z score for each select BSE-30 companies exhibit a significant change during last 5 years.

\section{ANALYSIS \& RESULT}

Table 3. Various ratios and Altman's Z score for sample companies.

\begin{tabular}{|c|c|c|c|c|c|c|c|}
\hline $\begin{array}{c}\text { Company } \\
\text { Name }\end{array}$ & YEAR & WC/TA & RE/TA & EBIT/TA & $\begin{array}{l}\text { MV OF } \\
\text { QUITY/ } \\
\text { Debt+CL }\end{array}$ & $\begin{array}{c}\text { Sales / } \\
\text { TA }\end{array}$ & $Z$ score \\
\hline \multirow{5}{*}{$\begin{array}{c}\text { Bajaj } \\
\text { Auto Ltd }\end{array}$} & $2010-2011$ & 0.231968 & 0.392081 & 0.372995 & 1.445118 & 1.477848 & 4.401599 \\
\hline & $2009-2010$ & 0.102327 & 3.187263 & 0.272291 & 0.185396 & 1.426155 & 7.019488 \\
\hline & $2008-2009$ & 0.169355 & 2.855013 & 0.061008 & 0.053567 & 1.542381 & 5.974548 \\
\hline & $2007-2008$ & 0.120514 & 2.920185 & 0.209805 & 0.062968 & 1.995339 & 6.956357 \\
\hline & 2006-2007 & 0.185389 & 0.465286 & 0.148185 & 0.264322 & 0.917655 & 2.438209 \\
\hline \multirow{5}{*}{$\begin{array}{c}\text { Bharti } \\
\text { Airtel } \\
\text { Ltd }\end{array}$} & $2010-2011$ & -0.03265 & 0.57647 & 0.123599 & 4.819077 & 0.817538 & 4.883924 \\
\hline & $2009-2010$ & -0.05416 & 0.634433 & 0.19958 & 6.368042 & 0.765883 & 6.067768 \\
\hline & 2008-2009 & & 0.514375 & 0.172437 & 5.420249 & 0.749705 & 5.209202 \\
\hline & $2007-2008$ & -0.09635 & 0.444083 & 0.036644 & 8.053781 & 0.656082 & 6.114713 \\
\hline & $2006-2007$ & -0.15841 & 0.34234 & 0.168271 & 9.583837 & 0.662725 & 7.256841 \\
\hline \multirow{5}{*}{$\begin{array}{l}\text { BHEL } \\
\text { Ltd }\end{array}$} & $2010-2011$ & 0.220227 & 0.294001 & & 0.443506 & 0.635997 & \\
\hline & $2009-2010$ & 0.247109 & 0.317701 & 0.136034 & 0.725535 & 0.691356 & 2.316209 \\
\hline & 2008-2009 & 0.249616 & 0.300136 & 0.115867 & 0.504984 & 0.692255 & 2.096645 \\
\hline & $2007-2008$ & 0.262647 & 0.292919 & 0.127662 & 0.761067 & 0.612278 & 2.214854 \\
\hline & 2006-2007 & 0.285362 & 0.321872 & 0.14166 & 0.623325 & 0.709732 & 2.343551 \\
\hline \multirow{5}{*}{$\begin{array}{c}\text { Cipla } \\
\text { Ltd }\end{array}$} & $2010-2011$ & 0.346521 & 0.663929 & 0.116668 & 5.278034 & 0.651005 & 5.547505 \\
\hline & $2009-2010$ & 0.35076 & 0.681039 & 0.151938 & 6.776222 & 0.666857 & 6.607686 \\
\hline & $2008-2009$ & 0.41614 & 0.611076 & 0.165073 & 4.326962 & 0.76934 & 5.264363 \\
\hline & $2007-2008$ & 0.410032 & 0.6274 & 0.134227 & 5.637662 & 0.738405 & 5.933613 \\
\hline & 2006-2007 & 0.404282 & 0.697389 & 0.17551 & 10.07357 & 0.832518 & 8.916494 \\
\hline \multirow{5}{*}{$\begin{array}{l}\text { Coal } \\
\text { India } \\
\text { Ltd }\end{array}$} & $2010-2011$ & 0.518373 & 0.474486 & 0.171981 & 25.17092 & 0.014963 & 16.97137 \\
\hline & 2009-2010 & 0.504767 & 0.448318 & 0.161078 & 26.3135 & 0.016824 & 17.56983 \\
\hline & $2008-2009$ & 0.476613 & 0.400866 & 0.163594 & 25.90286 & 0.012797 & 17.22751 \\
\hline & $2007-2008$ & 0.429801 & 0.357725 & 0.130646 & 28.6371 & 0.013812 & 18.64377 \\
\hline & 2006-2007 & 0.414433 & 0.332879 & 0.148851 & 28.50557 & 0.014777 & 18.57266 \\
\hline \multirow{3}{*}{$\begin{array}{l}\text { DLF } \\
\text { Ltd }\end{array}$} & $2010-2011$ & 0.507799 & 0.382357 & 0.040958 & 4.521714 & 0.082769 & 4.075534 \\
\hline & $2009-2010$ & 0.534058 & 0.431439 & 0.032018 & 6.994949 & 0.083563 & 5.630992 \\
\hline & 2008-2009 & 0.618701 & 0.478579 & 0.071882 & 4.770892 & 0.112449 & 4.624533 \\
\hline
\end{tabular}




\begin{tabular}{|c|c|c|c|c|c|c|c|}
\hline & 2007-2008 & 0.62109 & 0.466181 & 0.132992 & 19.3614 & 0.236023 & 13.68946 \\
\hline & 2006-2007 & 0.50507 & 0.030961 & 0.05537 & 19.99826 & 0.101158 & 12.93216 \\
\hline \multirow{5}{*}{$\begin{array}{c}\text { HDFC } \\
\text { Bank } \\
\text { Ltd }\end{array}$} & 2010-2011 & .527337 & 0.090364 & 0.014126 & 0.817494 & 0.08729 & 1.383627 \\
\hline & 2009-2010 & 0.550239 & 0.095263 & 0.013276 & 0.827564 & 0.089974 & 1.423889 \\
\hline & 2008-2009 & 0.497977 & 0.078135 & 0.012298 & 0.523337 & 0.108485 & 1.169923 \\
\hline & $2007-2008$ & 0.429665 & 0.083944 & 0.011939 & 0.958041 & 0.0925 & 1.339749 \\
\hline & 2006-2007 & 0.431994 & 0.067365 & 0.015141 & 0.979686 & 0.091988 & 1.342378 \\
\hline \multirow{5}{*}{$\begin{array}{c}\text { Hero } \\
\text { Motorcorp } \\
\text { Ltd }\end{array}$} & $2010-2011$ & & & & & & \\
\hline & 2009-2010 & -0.24657 & 0.401859 & 0.309725 & 77.57622 & 1.860887 & 49.69356 \\
\hline & $2008-2009$ & -0.19453 & 0.618032 & 0.274091 & 93.96997 & 2.030665 & 59.94692 \\
\hline & $2007-2008$ & & & & & & \\
\hline & 2006-2007 & -0.16355 & 0.572605 & 0.266767 & 74.40819 & 2.719633 & 48.84755 \\
\hline \multirow{5}{*}{$\begin{array}{c}\text { Hindalco } \\
\text { Industries } \\
\text { Ltd }\end{array}$} & $2010-2011$ & 0.036286 & 0.638619 & 0.058093 & 2.61592 & 0.516433 & 3.214786 \\
\hline & 2009-2010 & 0.032221 & & & & 0.466476 & 2.980405 \\
\hline & 2008-2009 & 0.100888 & 0.650618 & 0.070374 & 0.664627 & 0.502615 & 2.165055 \\
\hline & $2007-2008$ & 0.088078 & 0.554643 & 0.094476 & 2.918252 & 0.620118 & 3.564414 \\
\hline & 2006-2007 & 0.104968 & 0.492395 & 0.141264 & 4.547351 & 0.732292 & 4.741456 \\
\hline \multirow{5}{*}{$\begin{array}{l}\text { Hindustan } \\
\text { Lever Ltd }\end{array}$} & $2010-2011$ & -0.10712 & 0.23647 & 0.269119 & 8.038418 & 1.930576 & 7.842306 \\
\hline & $2009-2010$ & -0.11731 & 0.248433 & 0.289025 & 7.327954 & 1.862223 & 7.417948 \\
\hline & 2008-2009 & 0.008517 & 0.218067 & 0.34544 & 8.583803 & 2.437809 & 9.041119 \\
\hline & $2007-2008$ & -0.23738 & 0.178759 & 0.306468 & 8.812814 & 2.439509 & 8.701505 \\
\hline & $2006-2007$ & -0.16305 & 0.329765 & 0.241355 & 7.812546 & 1.807905 & 7.55611 \\
\hline
\end{tabular}

SPSS-19 software is being used to analyse the above data. To test the above hypothesis the altaman $\mathrm{Z}$ score of various companies were applied with One sample Kolmororov-Smirnov test, to identify that whetehr during the past 5 years the companies altman's $Z$ score have changed significantly or not. The result of hypothesis testing is shown in Table 4.

Table 4. Hypothesis test summery.

\begin{tabular}{|c|c|c|c|}
\hline Null Hypothesis & Test & Sig. & Decision \\
\hline $\begin{array}{c}\text { The distribution of Bajaj is normal with mean } \\
\text { 5.36 and standard deviation 1.95. }\end{array}$ & $\begin{array}{c}\text { One-Sample Kolmo- } \\
\text {-gorov Smirnov Test }\end{array}$ & 0.963 & $\begin{array}{c}\text { Retain the null } \\
\text { hypothesis. }\end{array}$ \\
\hline $\begin{array}{c}\text { The distribution of Bhar_Air is normal with } \\
\text { mean 5.91 and standard deviation 0.93. }\end{array}$ & $\begin{array}{c}\text { One-Sample Kolmo- } \\
\text {-gorov Smirnov Test }\end{array}$ & 0.979 & $\begin{array}{c}\text { Retain the null } \\
\text { hypothesis. }\end{array}$ \\
\hline $\begin{array}{c}\text { The distribution of BHEL is normal with } \\
\text { mean 2.20 and standard deviation 0.14. }\end{array}$ & $\begin{array}{c}\text { One-Sample Kolmo- } \\
\text {-gorov Smirnov Test }\end{array}$ & 0.987 & $\begin{array}{c}\text { Retain the null } \\
\text { hypothesis. }\end{array}$ \\
\hline $\begin{array}{c}\text { The distribution of Cipla is normal with } \\
\text { mean 6.45 and standard deviation 1.47. }\end{array}$ & $\begin{array}{c}\text { One-Sample Kolmo- } \\
\text {-gorov Smirnov Test }\end{array}$ & 0.893 & $\begin{array}{c}\text { Retain the null } \\
\text { hypothesis. }\end{array}$ \\
\hline
\end{tabular}




\begin{tabular}{|c|c|c|c|}
\hline $\begin{array}{c}\text { The distribution of Coal India is normal with } \\
\text { mean } 17.80 \text { and standard deviation 0.77. }\end{array}$ & $\begin{array}{c}\text { One-Sample Kolmo- } \\
\text {-gorov Smirnov Test }\end{array}$ & 0.930 & $\begin{array}{c}\text { Retain the null } \\
\text { hypothesis. }\end{array}$ \\
\hline $\begin{array}{c}\text { The distribution of DLF is normal with a } \\
\text { mean } 8.19 \text { and standard deviation } 4.71\end{array}$ & $\begin{array}{c}\text { One-Sample Kolmo- } \\
\text {-gorov Smirnov Test }\end{array}$ & 0.736 & $\begin{array}{c}\text { Retain the null } \\
\text { hypothesis. }\end{array}$ \\
\hline $\begin{array}{c}\text { The distribution of HDFC is normal with } \\
\text { mean } 1.33 \text { and standard deviation 0.10. }\end{array}$ & $\begin{array}{l}\text { One-Sample Kolmo- } \\
\text {-gorov Smirnov Test }\end{array}$ & 0.639 & $\begin{array}{c}\text { Retain the null } \\
\text { hypothesis. }\end{array}$ \\
\hline $\begin{array}{c}\text { The distribution of HERO_MOTO is normal } \\
\text { with mean 45.81 and standard deviation } \\
\text { 12.21. }\end{array}$ & $\begin{array}{l}\text { One-Sample Kolmo- } \\
\text {-gorov Smirnov Test }\end{array}$ & 0.937 & $\begin{array}{c}\text { Retain the null } \\
\text { hypothesis. }\end{array}$ \\
\hline $\begin{array}{c}\text { The distribution of HINDLKO is normal } \\
\text { with mean 3.33 and standard deviation 0.94. }\end{array}$ & $\begin{array}{l}\text { One-Sample Kolmo- } \\
\text {-gorov Smirnov Test }\end{array}$ & 0.986 & $\begin{array}{c}\text { Retain the null } \\
\text { hypothesis. }\end{array}$ \\
\hline $\begin{array}{c}\text { The distribution of HUL is normal with mean } \\
8.11 \text { and standard deviation 0.72. }\end{array}$ & $\begin{array}{l}\text { One-Sample Kolmo- } \\
\text {-gorov Smirnov Test }\end{array}$ & 0.923 & $\begin{array}{c}\text { Retain the null } \\
\text { hypothesis. }\end{array}$ \\
\hline
\end{tabular}

Asymptotic significance is displayed. The significance level is 0.05 . The above analysis explains that in case of all the companies despite of changes in the Altman's $Z$ score the difference is statistically not significant.

\section{CONCLUSION}

The application of financial distress measurement literature flows into the international application of credit risk measurement to verify the robustness of such measures and techniques in different countries. This measure creates a significant impact on other finance research since its ability to test existing hypotheses with the new continuous variable may hold promise for a new stream of studies. Workable and promising topics with the new credit risk measure are not limited to the following examples. Our hypothesis concerning Altman's Z-score is based on arguments that the Z-score have changed in the selected BSE companies, have found to be an unreached conclusion and all the companies are found to be in safe zone except HDFC Bank and BHEL. Finally we can conclude that Altman's model still exists and used by the companies for measuring creditworthiness of the companies and it still remains promising but challenging.

\section{References}

[1] Alkhatib K., Al Bzour A. E., International Journal of Business and Management 6(3) (2011) 208-215.

[2] Altman, E. I. Bankruptcy, Credit Risk and High Yield Junk Bonds. Blackwell (2002).

[3] Altman E. I., Journal of Finance 23 (1968) 589-609.

[4] Altman E.I., Haldeman R. G., Narayanan P., Journal of Banking and Finance 1 (1987) 29-54.

[5] Aziz M. A., Dar H. A., Corporate Governance 6(1) (2006) 18-33. 
[6] Back B., Laitinen T., Sere K., Wezel M. Chooking, Bankruptcy Predictions Using Discriminant Analysis, Logit Analysis, and Genetic Algorithms. Technical Report, Turku Center for Computer Science (1996) 40.

[7] Beaver W. H., Journal of Accounting Research 4 (1966) 71-111.

[8] Begley J., Mining J., Watts S., Review of Accounting Studies 1(4) (1996) 267-284.

[9] Ben-Horin M., Tcherikover (1996) 305-307.

[10] Charitou A., Trigeogis L., Option-Based Bankruptcy Predicion Working paper University of Cypus (2002).

[11] Chouhan V., The Pacific Business Review International 1 (2011) 70-75.

[12] Chouhan V., Bhatt A., Vyas D., The Indian Journal of Business Administration 7 (2011) 149-162.

[13] Chouhan V., The Indian Journal of Business Administration 6 (2010) 202-208.

[14] Christopoulos A., Vergos K., How Stock prices react to managerial decisions and other profit signaling events in the Greek mobile telecom market?, 3rd International Conference on Applied Financial Economics, Samos Island, (2006).

[15] Chung K. C., Tan S. S., Holdsworth D. K., International Journal of Business and Management 3(1) (2008) 19-29.

[16] Deakin E. B., Business failure prediction: An empirical analysis. In E. Altman, \& A. Sametz (Eds.), Financial crises: Institutions and markets in a fragile environment. New York, John Wiley (1977).

[17] Eden I., Meir Y., Roeh Haheshbon 5 (2007) 100-101.

[18] Gerantonis N., Vergos K., Christopoulos A. G., Research Journal of International Studies 12 (2009) 21- 28.

[19] Hillegeist S. A., Keeting E. K., Cram D. P., Lundstedt K. G., Assessing the Probability of Bankruptcy Working Paper, Northwestern University (2002).

[20] Ingbar Y., Analysis of financial statement Israel Institute of Productivity. (Chapter 13). (1994).

[21] Kim H., Gu Z., The Journal of Hospitality Financial Management 14(1) (2006) 17-34.

[22] Lawson R., Journal of Investing 17(4) (2008) 38-55.

[23] Lifschutz S., Jacobi A., International Journal of Business and Management 5(4) (2010) 133-141.

[24] Muller G. H., B. W. Steyn-Bruwer, W. D. Hamman, South African Journal of Business Management 40(1) (2009) 21-32.

[25] Odipo B. K., A.S. Itati, Evaluation of Applicability of ALTMAN'S Revised Model in Prediction of Financial Distress: A Case of Companies Quoted in the NAIROBI Stock Exchange (2011) 1-39.

[26] Ohlson J., Journal of Accounting Research 18 (1) (1980) 109-131.

[27] Santomero A. M., Vinso J. D., Journal of Banking and Finance 1 (1997) 185-205. 
[28] Smith R., A. Winakor, Changes in Financial Structure of Unsuccessful Industrial Corporations Bureau of Business Research, Bulletin No. 51. Urbana: University of Illinois Press (1935).

[29] Taffler R. J., Lu J., Kausar A., Journal of Accounting \& Economics 38(1-3) (2004) 263296.

[30] Wang Y., Campbell M., Journal of Business and Management 16(1) (2010) 75-88.

[31] Yu-Chiang Hu, Jake Ansell, Developing Financial Distress Prediction Models. A Study of US, Europe and Japan Retail Performance. University of Edinburgh, U.K (2005). 